\title{
SELECTION ACTING DIRECTLY ON AN ENZYME POLYMORPHISM
}

\author{
PHILLIP MORGAN \\ University of Nottingham, Department of Genetics, School of Biological Sciences, \\ University Park, Nottingham NG7 2RD
}

Received 11.vii.74

\section{SUMMARY}

A biochemical approach is utilised in the study of the maintenance of variation at the Adh locus in Drosophila melanogaster. There is a direct correlation between biochemical findings and the results of competition experiments. The relevance of these findings to the study of other enzyme polymorphisms is discussed.

\section{INTRODUCTION}

By means of electrophoresis about one-third of proteins have been shown to be polymorphic (Lewontin and Hubby, 1966). How is this protein variation maintained? There are two conflicting views. The neutralist view (Kimura and Ohta, 1971) states that the majority of protein variation is a product of mutation and drift, whilst the selectionist view (Clarke, 1970; Richmond, 1970) stresses the importance of selective forces. The argument can most clearly be resolved by methods which directly measure the selective forces (if any) acting at a particular locus. This paper presents such a method, applied to the alcohol dehydrogenase $(\mathrm{ADH})$ polymorphism in Drosophila melanogaster.

Much evidence suggests that selection influences gene-frequencies at this locus (Rasmuson et al., 1966; Kojima and Tobari, 1969; Gibson, 1970; Vigue and Johnson, 1973; Day et al., 1974). Until now, however, there has been no strong evidence that the observed changes in gene-frequency (Kojima and Tobari, 1969; Vigue and Johnson, 1973) are due to selection acting directly on the $A d h$ locus, rather than on other loci closely linked to it.

The enzyme produced by the $A d h^{F}$ allele has a greater specific activity than the enzyme produced by the $A d h^{S}$ allele when ethanol is used as a substrate (Rasmuson et al., 1966; Gibson, 1970). This difference in activity is also evident when a number of other alcohols are used as substrates (table 1). I have conducted experiments to find out if the difference in enzyme activities are reflected by selective differentials in experimental cultures of Drosophila.

\section{Materials and methods}

Homozygous lines for the $F$ and $S$ alleles were derived from the KadunA cage population at the Genetics Department, University of Nottingham. Each line consisted of the progenies of thirty pairs of homozygous parents. Each set of parents was obtained independently from the KADUNA population. The lines had been kept in population cages (as large populations) for approximately 18 months before the experiments were carried out. One hundred $F F$ and one hundred $S S$ newly emerged larvae (0-3 hours old) were collected for each experiment. They were put in a $10 \times 4 \mathrm{~cm}$ Drosophila vial containing $10 \mathrm{ml}$ of a medium resembling that of Kalmus (1943), 
except that it did not contain sucrose or ethanol; $110 \mathrm{mg}$ of the yeast Saccharomyces cerevisiae in $0.5 \mathrm{ml} \mathrm{H}_{2} \mathrm{O} / 10 \mathrm{ml}$ media were added to the control vials. $125 \mathrm{mg}$ of Saccharomyces cerevisiae in $0.5 \mathrm{ml} \mathrm{H}_{2} \mathrm{O} / 10 \mathrm{ml}$ media were added to the experimental vials as well as appropriate amounts of alcohol substrates. The amounts of alcohol added were those that gave approximately the same average mortality (regardless of genotype) as the controls. The components of the mixture were shaken until set, in order to disperse evenly the alcohol and the yeast. All emerging flies were electrophoresed, by the method of Day et al. (1974), to determine their Adh genotype.

TABle 1

The activities with various alcohols of crude extracts of enzymes produced by the allelic genes $\mathrm{Adh}^{F}$ and AdhS in Drosophila melanogaster (data of Day et al., 1974)

$\begin{array}{lccc}\text { Substrate* } & \begin{array}{c}\text { Activity } \begin{array}{c}\text { Activity of } \\ \text { F enzyme }\end{array} \\ S \text { enzyme }\end{array} & \begin{array}{c}\text { Ratio of } \\ \text { activities } F: S\end{array} \\ \text { Cyclohexanol } & 0 \cdot 1022 & 0.04915 & 2 \cdot 08 \\ \text { Ethanol } & 0.03488 & 0.01921 & 1.82 \\ \text { 3. N-butanol } & 0.07895 & 0.05236 & 1.51 \\ \text { 4. Iso-butyl alcohol } & 0.04511 & 0.03406 & 1.31 \\ \text { 5. N-propanol } & 0.03753 & 0.03089 & 1.21 \\ \text { 6. Iso-propanol } & 0.1250 & 0.04952 & 2 \cdot 52 \\ \text { 1-penten-3-ol } \ddagger & 0.05216 & 0.0163 & 3.2\end{array}$

* Cyclohexanol is completely oxidised in vivo (Tecwyn Williams, 1949). Alcohols numbered 2, 3, 4 and 5 are oxidised by alcohol dehydrogenase to aldehydes. Alcohols numbered 6 and 7 are oxidised by alcohol dehydrogenase to ketones.

$\dagger$ Activities were measured in a Pye-Unicam SP 1800 spectrophotometer. Saturated solution (or, in the case of ethanol and N-propanol, molar solutions) of the alcohols were prepared in phosphate buffer (pH 8-0). Equal weights of $F F$ and $S S$ flies were homogenised and the activities of the crude extracts compared at $25^{\circ} \mathrm{C}$, using the different alcohol substrates.

$\ddagger$ Author's data.

\section{Results AND DISCUSSION}

The results are given in table 2 . If in table 2 we exclude the results for iso-propanol (see below) then a comparison of tables 1 and 2 shows that the degree to which an alcohol selects for $F$ in the Drosophila vial is clearly related to the ratio of activities of $F$ and $S$ in vitro (regression of $\beta$ on $F: S$ ratio; $b=-0 \cdot 161, t=-5 \cdot 94, \mathrm{P}<0 \cdot 01)$. This relation is to be expected if the $\mathrm{ADH}$ enzyme detoxifies the alcohols, if the products of detoxification are nontoxic, and if the enzymic products of the two alleles act at different rates. The generality of these results has been confirmed by Van Delden and Bijlsma-meeles (personal communication) using Drosophila of different geographical origin, and different experimental methods.

The primary alcohols in table 2 are oxidised by $\mathrm{ADH}$ to aldehydes and these are presumably further broken down by aldehyde oxidase (Day et al., 1974). Cyclohexanol is completely oxidised in vivo (Tecwyn Williams, 1949). Iso-propanol is broken down by $\mathrm{ADH}$ into the ketone, acetone. Acetone is toxic, and notoriously difficult to oxidise in vivo (Tecwyn Williams, 1949). This fact probably accounts for the anomalous behaviour of iso-propanol in departing from the general association.

If the differences observed are, as they seem to be, due to selection acting directly on the Adh locus, then the following prediction can be made. In 
mixtures of $F F$ and $S S$ flies with an alcohol substrate that is metabolized by $\mathrm{ADH}$ to give a lethal product, the $S S$ flies should be at an advantage to the $F F$ flies (because $\mathrm{ADH}-F$ acts at a faster rate than $\mathrm{ADH}-S$ ). Such an alcohol is 1-penten-3-ol. It is reported to be oxidized by $\mathrm{ADH}$ to give a lethal ketone product, ethyl vinyl ketone (Sofer and Hatkoff, 1972). Using the method of Sofer and Hatkoff (1972), I have tested this prediction.

TABle 2

The relative advantages of $\mathrm{FF}$ fies over $\mathrm{SS}$ fies when grown on a medium with various alcohols

$\begin{array}{lcccccc} & \begin{array}{c}\text { Quantity added } \\ (\mathrm{ml}) / 10 \mathrm{ml} \\ \text { of medium }\end{array} & \begin{array}{c}F F \\ \text { input* }\end{array} & \begin{array}{c}\text { SS } \\ \text { input* }\end{array} & \begin{array}{c}F F \\ \text { survived }\end{array} & \begin{array}{c}\text { SS } \\ \text { survived }\end{array} & \begin{array}{c}\beta \text { value } \\ \text { for } F F \dagger\end{array} \\ \text { Substrate } & 0 \cdot 05 & 400 & 400 & 120 & 12 & 0 \cdot 2556 \\ \text { Eyclohexanol } & 0 \cdot 5 & 400 & 400 & 83 & 17 & 0 \cdot 3324 \\ \text { N-butanol } & 0 \cdot 1 & 400 & 400 & 80 & 22 & 0 \cdot 3569 \\ \text { Iso-butyl alcohol } & 0 \cdot 1 & 400 & 400 & 88 & 31 & 0 \cdot 3719 \\ \text { N-propanol } & 0 \cdot 25 & 400 & 400 & 98 & 57 & 0 \cdot 4192 \\ \text { Iso-propanol } & 0 \cdot 20 & 400 & 400 & 130 & 91 & 0 \cdot 4315 \\ \text { Control } & - & 400 & 400 & 60 & 49 & 0 \cdot 4745\end{array}$

* Each result is the sum of four pooled replicates (in every case the results of replicates were statistically homogeneous).

$\dagger$ Instead of displaying data as a final gene-frequency I have used the method of Manly (1972), which assigns the relative advantage or disadvantage to a particular morph. In this case the figures describe the relative advantage or disadvantage of the $F F$ morph. Values below 0.5 indicate a relative advantage. Values above 0.5 indicate a relative disadvantage.

$$
\beta=\log \frac{\log \left(\frac{F F \text { put in }}{F F \text { survived }}\right)}{\left.\frac{F F \text { put in }}{F \text { survived }}\right)+\log \left(\frac{S S \text { put in }}{S S \text { survived }}\right)}
$$

TABLE 3

The effect of exposure to 1-penten-3-ol on the survival of FF and SS fies

\begin{tabular}{|c|c|c|c|c|c|c|}
\hline $\begin{array}{l}\text { Number of } \\
\text { flies exposed }\end{array}$ & $\begin{array}{l}\text { Number of } \\
\text { replicates }\end{array}$ & Sex & $\mathrm{ADH}$ genotype & Died & Survived & $\begin{array}{l}\text { Percentage } \\
\text { survival }\end{array}$ \\
\hline $\left.\begin{array}{l}430 \\
430\end{array}\right\}$ & 10 & $\left\{\begin{array}{l}\text { Female } \\
\text { Male }\end{array}\right.$ & $\begin{array}{l}F F \\
S S\end{array}$ & $\begin{array}{l}277 \\
194\end{array}$ & $\begin{array}{l}153 \\
236\end{array}$ & $\begin{array}{l}35 \cdot 6 \\
54 \cdot 8\end{array}$ \\
\hline $\left.\begin{array}{l}259 \\
259\end{array}\right\}$ & 7 & $\left\{\begin{array}{l}\text { Male } \\
\text { Female }\end{array}\right.$ & $\begin{array}{l}F F \\
S S\end{array}$ & $\begin{array}{l}186 \\
102\end{array}$ & $\begin{array}{r}73 \\
157\end{array}$ & $\begin{array}{l}28 \cdot 1 \\
60 \cdot 6\end{array}$ \\
\hline
\end{tabular}

In each experiment, equal numbers of $F F$ and $S S$ flies (the $F F$ flies being of one sex, the $S S$ of the other) were placed in a container and exposed to the vapour of a freshly prepared solution of 0.5 per cent 1-penten-3-ol in water for approximately $1 \frac{1}{4}$ minutes. After this time the flies were transferred to a vial containing normal Drosophila medium. After a further 12 hours the flies which had died were counted and sexed. The flies used in these experiments were 4 days old (for explanation see Sofer and Hatkoff, 1972). The association between sex and genotype was changed from experiment to experiment.

Of 17 replicate experiments, two gave a non-signficant result and in the other 15 a significantly greater number of $F F$ flies died after the treatment 
(see table 3). Even without statistically testing the results of individual experiments the total number of experiments going in the expected direction $(15 / 17)$ is itself clearly significant $(\mathrm{P}<0.002$ by the median test $)$.

Using the same experimental design I have exposed flies to the vapour of ethyl vinyl ketone (the ketone produced by the oxidation of 1 -penten-3-ol by $\mathrm{ADH})$. There is no significant difference in survival rate between $F F$ and $S S$ flies. This result means that the differential survival is related to differential activity and not to differential susceptibility to the ketone.

It can be concluded that the variation at the $A d h$ locus in $D$. melanogaster is not neutral to applied selection. There is good evidence that the selection acts directly on this locus rather than on other loci linked to it.

The principle of searching for the direct effects of selection, by correlating knowledge of the biochemical properties of enzyme variants with changes of gene-frequencies in experimental populations can be applied to other enzyme polymorphisms. By these means the question "How is protein variation maintained?" could perhaps be finally and conclusively answered.

Acknowledgments. - I am indebted to the following for discussions and criticisms of the manuscript: Professor B. C. Clarke; Mr R. Griffiths; Dr M. S. Johnson; Dr T. H. Day and Mr D. T. Horsley.

\section{References}

Clarke, B. 1970. Darwinian evolution of proteins. Science, 168, 1009-1011.

DAY, T. H., Hillier, P. C., AND ClARKE, B. c. 1974. Properties of genetically polymorphic isozymes of alcohol dehydrogenase in Drosophila melanogaster. Biochem. Genet., 11, 141 153.

GIBson, J. 1970. Enzyme flexibility in Drosophila melanogaster. Nature, 227, 959-960.

kalmus, H. 1943. A factorial experiment on the mineral requirements of a Drosophila culture. Amer. Natur., 77, 376-380.

kimura, M., AND OHTA, T. 1971. Protein polymorphism as a phase of molecular evolution. Nature, 229, 467-469.

KojIMA, K. I., AND тоBARI, Y. N. 1969. The patterns of viability changes associated with genotype frequency at the alcohol dehydrogenase locus in Drosophila melanogaster. Genetics, 61, 201-209.

LEwONTIN, R. C., AND HUBBY, J. L. 1966. A molecular approach to the study of genic heterozygosity in natural populations. II. Amount of variation and degree of heterozygosity in natural populations of Drosophila pseudoobscura. Genetics, 54, 595-609.

ManLy, B. F. J. 1972. Tables for the analysis of a selective predation experiment. Res. Popul. Ecol., 14, 74-81.

RASMUSON, B., NILSON, L. R., RASMUSON, M., AND ZEPPEZAUER, E. 1966. Effects of heterozygosity on alcohol dehydrogenase $(\mathrm{ADH})$ activity in Drosophila melanogaster. Hereditas, $56,313-316$.

RICHMOND, R. C. 1970. Non-Darwinian evolution: A critique. Nature, 225, 1025-1028.

SOFER, W. H., AND HATKOFF, M. A. 1972. Chemical selection of alcohol dehydrogenase negative mutants in Drosophila. Genetics, 72, 545-549.

TeCWYN Williams, R. 1949. Detoxication Mechanisms. Chapman and Hall, London.

vigue, c. L., AND JOHNson, F. M. 1973. Isozyme variability in species of the genus Drosophila.

VI. Frequency-property-environment relationships of allelic alcohol dehydrogenase in D. melanogaster. Biochem. Genet., 9, 213-227. 